\title{
Developing the Program to Strengthen Working Achievement Motivation Competencies of Welfare School's Teachers
}

\author{
Suraphan Weerason ${ }^{1}$, Kowat Tesaputa ${ }^{2}$ \& Anong Phuetsing ${ }^{3}$ \\ ${ }^{1}$ Faculty of Education, Mahasarakham University, Thailand \\ ${ }^{2}$ Faculty of Education, RoiEt Rajabhat University, Thailand \\ ${ }^{3}$ Director of Thawatburi Welfare School, RoiEt, Thailand \\ Correspondence: Suraphan Weerason, Faculty of Education, Mahasarakham University, Thailand.
}

Received: April 9, 2021

Accepted: August 5, $2021 \quad$ Online Published: October 27, 2021

doi:10.5539/ies.v14n11p75

URL: https://doi.org/10.5539/ies.v14n11p75

\begin{abstract}
This research aimed: 1) to investigate the components and indicators of working achievement motivation competencies of welfare school's teachers; 2) to examine the needs to develop working achievement motivation competencies of welfare school's teachers; and 3) to develop the program to strengthen working achievement motivation competencies of welfare school's teachers. The mixed methods research was employed by divided into three phases. Phase one, investigated the components and indicators of the working achievement motivation competencies. Components and indicators were verified by 7 experts. Phase two, examined the needs to develop working achievement motivation competencies of welfare school's teachers. The respondents were 340 welfare school's teachers. Phase three, to develop the program to strengthen working achievement motivation competencies of welfare school's teachers and verified the program by 9 experts. The research instruments were the components and indicators evaluation form, the existing and desirable situations questionnaire of working achievement motivation competencies, and the program evaluation form. Statistics used in analyzing data were mean, standard deviation and priority needs index modification. The research findings were: 1) The components and indicators of working achievement motivation competencies of welfare school's teachers were categorized into 6 components and 32 indicators; 2) The needs to develop working achievement motivation competencies of welfare school's teachers were ranked from high to low: creativity, performance commitment, performance evaluation, flexibility, the quest for information, and development of operational competence; and 3) The program to strengthen working achievement motivation competencies of welfare school's teachers consisted of rationale, objectives, content, model and methods, 6 modules of program structure, and application and evaluation.
\end{abstract}

Keywords: program, working achievement motivation competencies, welfare school's teachers

\section{Introduction}

A teacher is the one who transmits knowledge to learners and create activities to facilitate students learning. A teaching job is a profession. A teacher plays a very important part to motivate and encourage children to learn and achieve the set goals. According to the Ministry of Education, it is very essential for the teachers to develop themselves. It is important that the development should be centered on competency. Teamwork is very essential as it can lead to the culture of working with others and be very effective (Aporn, 2001). At present, the concept of the potential or competence is vital and put into use in educational management, especially the achievement potential competency measurement focuses on the real-world tasks and responses to them recognizing a multitude of abilities are involved in performance and pulling them apart distorts the performance of greatest interest (McClelland, 1973; Shavelson et al., 2002).

Government and Ministry of Education recognize the value of human resources, especially government officials, teachers in schools close to parents and students. Therefore, tried to find a way to forecast ability, as can be seen from the Teacher Civil Service Regulation Act and Educational Personnel, 2004, Section 42, the Office of the Teacher Civil Service and Educational Personnel Commission set the position standards. Academic standard Set as the norm in all academic institutions for use in their work Office of the Basic Education Commission (2010) develop competency of Thai teachers have 2 main components of competencies, that is 1) Core Competency included 5 sub-competencies: working achievement motivation, service mind, self-development, team work, and 
teacher's ethics and integrity; and 2) Functional Competency included 6 sub-competencies: curriculum and learning management; student development; classroom management; analysis, synthesis and Classroom research; teacher leadership; and relationship and collaborative for Learning.

Based on the observation of the performance of the welfare school's teachers, the following were found it was necessary for the teachers to maximize their potential. The schools had different methods in developing the potential. Some schools had no personnel development; as a result, the teachers had the achievement potential in their performance. Furthermore, learners' learning achievement was unsatisfactory, and the set goals did not materialize. With the performance results different from those found in the schools affiliated to the Office of the Basic Education Commission, the general public were likely to assume that the teachers of this type of the schools had to be somehow different in terms of competency and other attributes. On the contrary, in general schools (Anong, 2010), absolutely, working achievement motivation is important for developing that mean commitment in performing duties for quality complete with creativity with planning, setting goals, monitoring and evaluating performance and improve the efficiency and performance continuously because, the teacher of welfare schools was low of working achievement motivation. With the reasons described above, the research was conducted to develop the working achievement motivation competencies of the teachers in welfare schools to enhance learners' quality.

\section{Research Methodology}

The mixed methods research was employed by divided into three phases.

Phase 1: An investigation of the components and indicators of working achievement motivation competencies of welfare school's teachers comprising following steps:

Step 1: review of the related literature and synthesized the components and indicators of working achievement motivation competencies.

Step 2: evaluated the appropriateness of components and indicators by 7 experts.

Phase 2: an examined the needs to strengthen of working achievement motivation competencies of welfare school's teachers. Survey research technique was employed by using 5-rating scales questionnaire of existing and desirable situations. Data collected from the samples were 340 teachers in the welfare schools. Priority needs modification index was used to analyzing data.

Phase 3: designed the program of working achievement motivation competencies of welfare school's teachers divided into 3 steps:

Step 1: examined the two school best practices were selected based on the criteria of outstanding performance and the awards they had won. The two schools were Ratprachanukroh School 28 in Yasothorn province and Ratprachanukroh School 50 in Khonkaen province. The informants were the teachers from two schools with the best practices. Data collected from the samples were 30 teachers in the two welfare schools.

Step 2: the results obtained in step 1 were synthesized to develop the program of working achievement motivation competencies of welfare school's teachers.

Step 3: evaluating the program of working achievement motivation competencies of welfare school's teachers by 9 experts.

\section{Result}

The research results were as follows:

I. As regards the working achievement motivation competencies of welfare school's teachers, 6 components and 32 indicators were obtained:

a) Component one: performance commitment had 6 indicators. They were: 1) analysis of the mission to systematically plan, 2) determination of the targets in all semesters, 3) determining the practical plan and managing the learning lesson step by step, 4) being enthusiastic to learn, 5) being creative in developing the learning, 6) searching for knowledge on new professions.

b) Component two: creativity had 4 indicators: originality, fluency, flexibility, elaboration.

c) Component three: the quest for information had 6 indicators. They were 1) search for new academic and professional knowledge; 2) collecting and synthesizing data, knowledge and categorizing them; 3) creating elements of knowledge and innovation for the learning management; 4) exchanging and sharing knowledge and experience with others; 5) counselling, advising and transmitting knowledge and professional experience; 6) creating a learning network. 
d) Component four: flexibility had 5 indicators: being active in working, and adjusting to unfavorable conditions; accepting the need to change, and being willing to listen to others; being judicious in adjusting the rules and regulations according to the situations; changing the way to work in commensurate with the circumstances to increase the efficiency; changing the strategic plans, targets or program to make them suitable to the situations.

e) Components five: development of operational competence had 7 indicators as follows: 1) using the performance evaluation to improve the results, 2) performing in response to the needs of learners, parents and communities; 3) developing according to the set plan; 4) participating in activities and cooperating in managing knowledge; 5) cooperating to develop the potential of others; 6) providing the counselling in a creative way; 7) exchanging opinions and building a network.

f) Component six: performance evaluation had 4 indicators: evaluation, result orientation, focus on goals and targets, and setting a mutual goal between supervisors and employees.

II. The order of needs to development of working achievement motivation competencies of welfare school's teachers sorted by descending order: creativity, performance commitment, performance evaluation, flexibility, the quest for information, development of operational competence respectively as shown in Table 1.

Table 1. Existing situations mean (D), desirable situations mean (I), priority needs modification Index (PNImodified), and order of needs

\begin{tabular}{lcccc}
\hline Achievement motivation competencies & D & I & PNImodified & Order \\
\hline 1. Performance commitment & 3.94 & 4.46 & 0.132 & 2 \\
2. Creativity & 3.79 & 4.36 & 0.150 & 1 \\
3. The quest for information & 3.79 & 4.19 & 0.106 & 5 \\
4. Flexibility & 3.80 & 4.22 & 0.111 & 4 \\
5. Development of operational competence & 3.95 & 4.32 & 0.094 & 6 \\
6. Performance evaluation & 3.94 & 4.4 & 0.117 & 3 \\
\hline
\end{tabular}

III. The program to strengthen working achievement motivation competencies of welfare school's teachers verified by 9 experts, which had six modules and a total of 116 hours. According to the experts, the program was suitable, possible and useful at the highest level. There were four methods to develop the working achievement motivation competencies of welfare school's teachers: site visiting, coaching, planning for individuals and professional learning community as shown in Figure 1. 


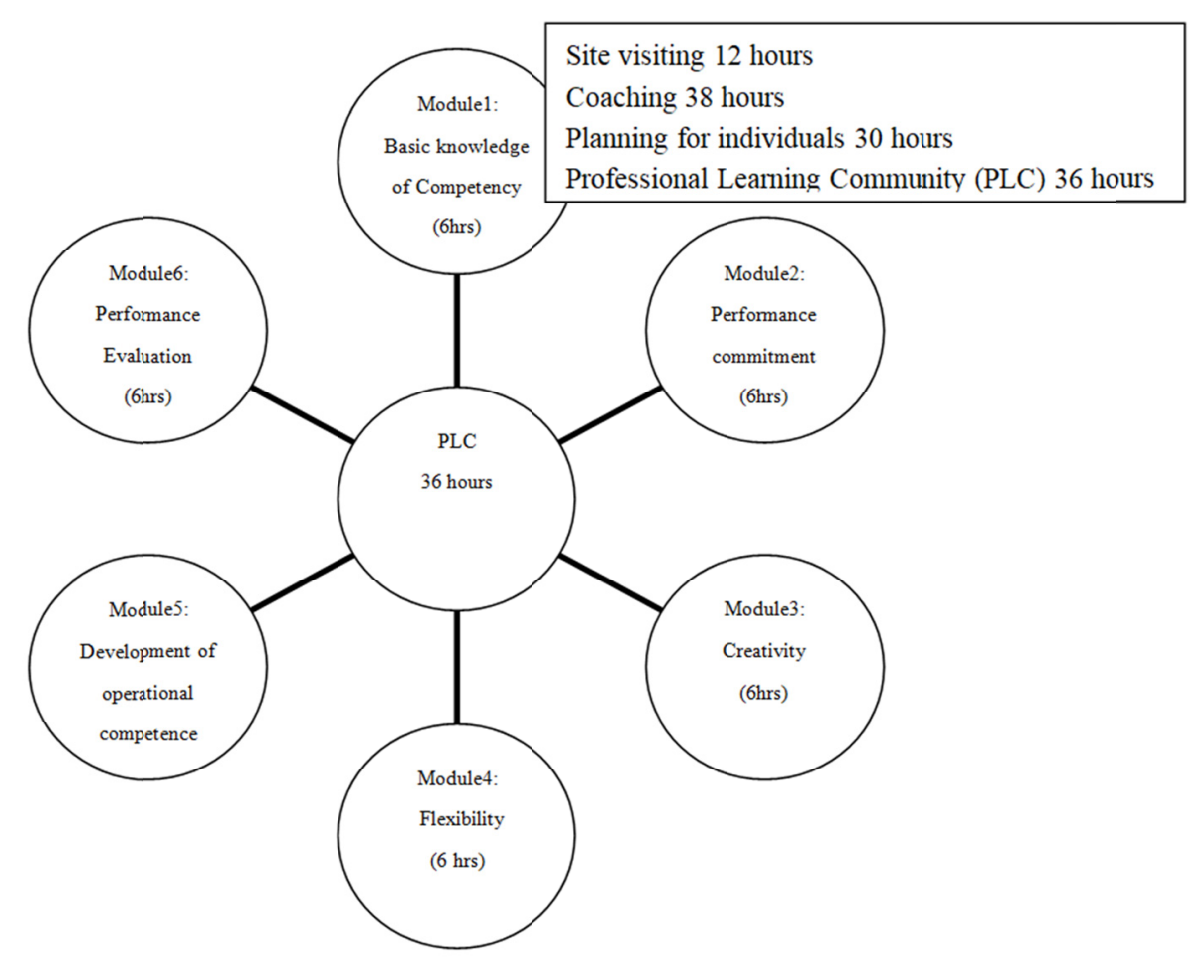

Figure 1. The program to strengthen working achievement motivation competencies

Site visiting (12 hours): Listen to a lecture talk about work experience. As well as working techniques to give teachers an idea of competencies. Asking questions to exchange knowledge by asking from what he had seen Asking questions sparked ideas. Encourage the transfer of knowledge in work to techniques and methods of work to be effective such as reducing operating procedures, adopting modern technology, adopting modern management methods which inquire to build this knowledge, apply the knowledge gained from site visiting to apply to work, takes 12 hours.

Coaching (38 hours): Senior teachers who teach one-on-one work and help new teachers try to develop working achievement motivation competencies of welfare school's teachers. Additionally, group reflection for sharing their ideas takes 38 hours.

Planning for individuals (30 hours): from the order of needs to strengthen of working achievement motivation competencies of welfare school's teachers plan to develop each Module, then target group assess by themselves. next step Group reflection with Senior teachers takes 30 hours.

\section{Conclusions and Recommendations}

The research conclusions can be discussed in the followings:

I. As regards the working achievement motivation competencies of welfare school's teachers, six components were derived: Performance commitment, creativity, the quest for information, flexibility, development of operational competence, and performance evaluation. Thirty-two indicators were obtained.

A study of relevant research works found that the present work was in accordance with who stated that there were five components of the competence: knowledge, skills, self-concept, traits, and motives /attitudes (McClelland, 1973). These components could lead a person to a set goal. Houston (1972) stated that for the person to develop the capability to perform something, it was crucial to develop it in three stages: 1) developing awareness, knowledge and skills, 2) action or practice and 3) experience in doing to make things effective. Likewise, Boyatzis (1982) explained that the faculty model consisted of five elements: motives, traits, self-image, social and skills. Furthermore, Spencer and Spencer (1993) held a similar view that the competency comprised key five components as follows. 1) Motives referred to the things the person constantly contemplated or wanted. It could lead the person to act. Meanwhile it guides the direction or makes one's behavior different from others. 2) Traits described physical characteristics and constant response to circumstances or received news. 3) Self-concept meant the personal trait, values, beliefs and attitudes. 4) Knowledge dealt with the 
information or news the person had got for any given event. 5) Skills covered an expressed ability or bodily and mental action. Similarly, Narongwit (2004) classified the competency into three types: 1) personal competency was an individual or collective ability, for example, ability to draw, and an ability of the inventors. This type of abilities was difficult to imitate. 2) Job competency was ability specific for the position or role required for the job to be carried out, for example the ability to analyze the academic positions. 3) Organization competency was a specific type for the organization, for example the school named Mahidolwittanusorn was renowned for the science teaching. In addition, the components of the model included innate capacity, and acquired capability, a competency derived from learning and experience. On top of the model were the following: behavior, skills, knowledge, attitude, personal characteristics. Jansiri (2008) conducted a study similar to those described above. He studied, analyzed the techniques, and the structure of the development. He found that the main competency was found in teamwork, planning and management, leadership, creativity, and ethics. Office of the Basic Education Commission (2010) had developed the potential and indicators of Thai teachers. The core competency consisted of: will to success, good service, self-development, teamwork, and ethics and code of conduct for professions. The functional competency included a curricular administration and learning management, a learner development, a classroom administration, an analysis and research for the learner development, a teacher's leadership, relations and cooperation with the communities.

II. The needs to development the working achievement motivation competencies of welfare school's teachers sorted by descending order: creativity, performance commitment, performance evaluation, flexibility, the quest for information, development of operational competence respectively. The finding was in congruence with Queensland University of Tecnology (Cited in Dechagupta \& Khaengkhan, 2008) found that most teachers in Thailand were rejected. Teaching has to be a factor that drives teachers to change the concept of teacher-centered come to the students as a center for competencies that must be developed for teacher's Up-to-date knowledge in Teaching Areas Strategies for learning management Teaching Evaluation Measurement Integrated use of information technology. The role of learning advisor and conducting research in the classroom. Additionally, with Sangngam (2012) who studies the factors influencing the needs of the development of teaching competencies of primary school teachers teaching mismatch their educational background in Sisaket Province: Analysis a multilevel finding is necessary to develop the highest teaching competencies. The top three are research, curriculum development, and learning management.

III. The program to strengthen working achievement motivation competencies of welfare school's teachers, which had six modules and a total of 116 hours. There were four methods to develop the working achievement motivation competencies: site visiting, coaching, planning for individuals and professional learning. The program evaluated by the experts was found to be suitable, possible and useful at the highest level. The finding was in congruence with the study of Anan (2011) who conducted a research on the ability development for the school administrators. He found that the evaluation results showed that the school administrators had a different level of knowledge of the competency before and after the development at a statistical significance of .01. The test results showed that the school administrators had a different result before and after the development at a statistical significance of .01 . The efficiency of the performance before and after the development was different with a statistical significance of .05. Boone and Kurtz (1989) explained that in the program development, it was essential to understand or accept the fundamental agreements on the development. In this respect, there were five aspects: 1) the development to bring about changes in learners in light of knowledge, skills, attitudes and so on; 2) the development was concerned with a decision, thus it was necessary to involve those concerned; 3) the development was a matter of cooperation or participation of the participants; 4) the development was concerned with the system and concept, which included the planning system, creation and application, and evaluation; 5) the development kept the organization full awake and updated.

In accordance with Styles (1990) proposed the Program Development Model consisting of 1) Needs Assessment 2) Goal Setting 3) Planning Team 4) Staff Development 5) Evaluation 6) Modes of Implementation 7) Resource Management 8) Environment Assessment in accordance with Boone and Kurtz (1989) Proposed that in the development of the program Educators or program developers should have a basic understanding. Or accept a preliminary agreement on program development 5 items 1) Program development is the hope that changes occur in the learner, whether the learner. Will be individual It is a group of people or a community. The expected change to learners is in knowledge, skills, and attitudes at the group or community level. It takes place in the community as a means of coordinating the needs and interests of different groups.

\section{References}

Anan, P. (2011). Research and Development of the Competence of the Administrators (Ph.D. dissertation, Khonkaen University). 
Anong, P. (2010). A Development of the Effective Administrative System in the Welfare Schools (Ed.D. dissertation, Mahasarakarm University).

Aporn, P. (2001). Human Resource Management and Development Case Study. Bangkok: HR Center.

Boone, L. E., \& Kurtz, D. L. (1989). Consumer behavior (7th ed.). London: Prentice-Hall.

Boyatzis, R. E. (1982). The Competence manage: A model for effective performance. New York: Wiley.

Dechagupta, P., \& Khaengkhan, P. (2008). Competency and approach to teacher development in a changing society. Office of the Education Council Secretariat Ministry of Education. Bangkok: SorKorSor.

Erawan, P. (1999). Classroom Research. Bangkok: Upack.

Houston. (1972). Developing Instruction Modules: A Modulate System for Writing Modules. Texas: College Education, Texas University of Houston.

Jansiri, W. (2008). A Development of the Competency of the Administrators in the State Universities (Ed.D. dissertation, Mahasarakarm University).

McClelland, D. C. (1973). Testing for Competence rather than for Intelligence. American Psychologist. https://doi.org/10.1037/h0034092

Narongwit, S. (2004). Knowing Competency. Bangkok: HR Center.

Office of the Basic Education Commission. (2010). A Handbook for a Teacher Competence. Bangkok: Ministry of Education.

Office of the Civil Servant Commission. (2004). Application of the competence in Human Resources. Paper for Seminar, 31 January 2004.

Office of the Civil Servant Commission. (2005). Competence of the Government Officials. Bangkok: Ministry of Education.

Office of the Teachers Council. (2005). Standard of the Education Professions. Bangkok: Teachers Council Secretariat.

Sangngam, B. (2012). Factors influencing the need for development Teaching competencies of primary school teachers who teach inadequate qualifications Education in Sisaket Province: A level analysis (Master of Education Thesis, Maha Sarakham: Mahasarakham University).

Secretariat of the Teachers Council. (2008). Ability of Thai Education on the International Stage. Bangkok.

Secretariat of the Teachers Council. (2009). Circumstances of Thai Education in the International Stage. Bangkok Prikwarn.

Shavelson, R. J., Roeser, R. W., Kupermintz, H., Lau, S., Ayala, C., Haydel, A., ... \& Quihuis, G. (2002). Richard E. Snow's remaking of the concept of aptitude and multidimensional test validity: Introduction to the special issue. Educational Assessment, 8(2), 77-99. https://doi.org/10.1207/S15326977EA0802_01

Spencer, L. M., \& Spencer, S. M. (1993). Competence at Work: Models for Superior Performance. John Wiley \& Sons, New York.

Wijarn, P. (2004). Schools and Knowledge Management. Bangkok.

\section{Copyrights}

Copyright for this article is retained by the author(s), with first publication rights granted to the journal.

This is an open-access article distributed under the terms and conditions of the Creative Commons Attribution license (http://creativecommons.org/licenses/by/4.0/). 